\title{
No evidence for preferential X-chromosome inactivation as the main cause of divergent phenotypes in sisters with X-linked hypohidrotic ectodermal dysplasia
}

\author{
Laura Körber ${ }^{1}$, Holm Schneider ${ }^{1}$, Nicole Fleischer ${ }^{2}$ and Sigrun Maier-Wohlfart ${ }^{1 *}$ (1)
}

\begin{abstract}
Background: X-linked hypohidrotic ectodermal dysplasia (XLHED), a rare genetic disorder, affects the normal development of ectodermal derivatives, such as hair, skin, teeth, and sweat glands. It is caused by pathogenic variants of the gene EDA and defined by a triad of hypotrichosis, hypo- or anodontia, and hypo- or anhidrosis which may lead to life-threatening hyperthermia. Although female carriers are less severely affected than male patients, they display symptoms, too, with high phenotypic variability. This study aimed to elucidate whether phenotypic differences in female XLHED patients with identical EDA genotypes might be explained by deviating $X$-chromosome inactivation (XI) patterns.
\end{abstract}

Methods: Six families, each consisting of two sisters with the same EDA variant and their parents (with either mother or father being carrier of the variant), participated in this study. XLHED-related data like sweating ability, dental status, facial dysmorphism, and skin issues were assessed. We determined the women's individual XI patterns in peripheral blood leukocytes by the human androgen receptor assay and collated the results with phenotypic features.

Results: The surprisingly large inter- and intrafamilial variability of symptoms in affected females was not explicable by the pathogenic variants. Our cohort showed no higher rate of nonrandom XI in peripheral blood leukocytes than the general female population. Furthermore, skewed XI patterns in favour of the mutated alleles were not associated with more severe phenotypes.

Conclusions: We found no evidence for preferential XI in female XLHED patients and no distinct correlation between XLHED-related phenotypic features and XI patterns. Phenotypic variability seems to be evoked by other genetic or epigenetic factors.

Keywords: X-linked hypohidrotic ectodermal dysplasia, Ectodysplasin A, Female carriers, X-chromosome inactivation, Genotype-phenotype correlation

*Correspondence: sigrun.maier-wohlfart@uk-erlangen.de

${ }^{1}$ Center for Ectodermal Dysplasias and Department of Pediatrics, University Hospital Erlangen, Loschgestr. 15, 91054 Erlangen, Germany

Full list of author information is available at the end of the article

\section{Introduction}

X-chromosomal hypohidrotic ectodermal dysplasia (XLHED; MIM \#305100) is a rare combined malformation of ectodermal tissues such as hair, teeth, and sweat glands, resulting in hypotrichosis, hypo-, oligo- or anodontia and hypo- or anhidrosis $[1,2]$. The most crucial deficiency is the strongly reduced or missing ability to original author(s) and the source, provide a link to the Creative Commons licence, and indicate if changes were made. The images or other third party material in this article are included in the article's Creative Commons licence, unless indicated otherwise in a credit line to the material. If material is not included in the article's Creative Commons licence and your intended use is not permitted by statutory regulation or exceeds the permitted use, you will need to obtain permission directly from the copyright holder. To view a copy of this licence, visit http://creativecommons.org/licenses/by/4.0/. The Creative Commons Public Domain Dedication waiver (http://creativeco mmons.org/publicdomain/zero/1.0/) applies to the data made available in this article, unless otherwise stated in a credit line to the data. 
sweat, potentially leading to life-threatening hyperthermia, especially in infants [3]. Numerous pathogenic variants of the ectodysplasin A gene (EDA; NM_001399.4) are known to cause malfunctioning of the signaling protein EDA1 [4]. The presence of a certain single nucleotide polymorphism (SNP) rs3827760 (c.1109T $>C$; p.Val370Ala) in the gene EDAR (NM_022336.3; coding for the ectodysplasin A receptor) has been discussed to alleviate XLHED-related issues [5].

Beside the cardinal symptoms mentioned above, patients may show typical signs of facial dysmorphia (periorbital wrinkles and hyperpigmentation, frontal bossing, prominent lips, protruding ears). Due to the defective development of eccrine glands, individuals with XLHED often suffer from a very dry and/or eczematous skin, atrophic rhinitis, dry eyes, respiratory ailments, and in case of females, malformation of mammary glands [1,2,6-10].

Following an X-linked recessive inheritance pattern, normally only hemizygous males show the complete cluster of symptoms while heterozygous women were primarily considered as carriers. Although many females heterozygous for an $E D A$ variant are indeed more mildly affected than male patients, they often do present distinct symptoms of pathological significance. They may lack numerous teeth and sweating ability [6] and, as a result of deficient breast development (which goes as far as unior bilateral amastia), difficulties with breastfeeding are experienced frequently [11].

Female XLHED patients with identical pathogenic $E D A$ variants (e.g., sisters) occasionally present phenotypic features that vary in expression, which might be explained through the mechanism of preferential X-chromosome inactivation (XI). Usually, women show a random inactivation of one of the two $\mathrm{X}$ chromosomes in each somatic cell, which leads to an approximate 50:50 ratio of maternal to paternal X-chromosome expression (lyonization for dosage compensation) [12]. However, there are also women with a preferential or skewed XI, a phenomenon occasionally (but not exclusively) found in carriers of X-linked diseases. In these cases the ratio differs in favour of one of the two X-chromosomes, mostly that of the healthy wild-type allele, probably due to selective advantages of these cells. Cases of XLHED were discussed previously in this context [13-16].

So far, XLHED patients have been treated merely symptomatically. However, a new therapeutic approach appears to be very promising: the prenatal administration of a recombinant EDA1 molecule, which has already been applied to several boys (named patient use) resulting in normal sweating ability and improved dentition [17]. In order to evaluate this prenatal treatment, a clinical trial for yet unborn male patients is being prepared.
The study presented here could lead to a better understanding of potential genotype-phenotype correlations in women with XLHED who have received only little scientific attention so far. These insights will most likely be of significance when it comes to the question whether affected females might also benefit from prenatal drug therapy.

\section{Subjects and methods \\ Study design and patients}

Six families (F1-F6), each consisting of two sisters (S1 and $S 2)$ and their parents ( $M$, mother; one pair of siblings has different biological fathers), were included in this study. All sisters are carriers of pathogenic EDA variants with maternal inheritance in four and paternal inheritance in two of the familial cases.

\section{DNA analysis}

DNA isolation from peripheral blood, polymerase chain reaction and subsequent Sanger sequencing were performed as described previously [18]. Specific oligonucleotide primer sequences and thermal cycling conditions for the detection of $E D A$ and $E D A R$ variants are available upon request.

\section{Clinical status and tooth quantification}

Anthropometric data included body length in $\mathrm{cm}$, weight in $\mathrm{kg}$ and body mass index (BMI) in $\mathrm{kg} / \mathrm{m}^{2}$. HED-relevant issues (including general health, heat intolerance, dentition, skin and hair abnormalities) were assessed by questionnaires and physical examinations.

\section{Assessment of sweating ability}

Quantification of pilocarpine-induced sweating (volumetry) in an area of $57 \mathrm{~mm}^{2}$ of the forearm for 30 min using the Wescor 3700 device (Wescor, Logan, USA) was performed as described before [17].

\section{Face2Gene analysis}

Face2Gene (https://www.face2gene.com/), a next generation phenotyping tool developed by FDNA Inc. (Boston MA, USA), uses a facial recognition algorithm called DeepGestalt for evaluation of facial dysmorphisms. This technology quantifies similarities of facial frontal photographs of patients with hundreds of different syndromes the system has been trained on, resulting in a list of possible syndrome matches, ranked by a score called Gestalt Score (between 0 and 1) [19].

\section{HUMARA assay}

The human androgen receptor (HUMARA) assay, a PCRbased method for the investigation of X-inactivation patterns, enables the discrimination between the maternal 
and paternal as well as the active and inactive $\mathrm{X}$ chromosome. A highly polymorphic trinucleotide repeat of exon 1 of the HUMARA gene allows to distinguish the two alleles (via their individual nucleotide length) and is informative in about $90 \%$ of all females. Cleavage sites for methylation sensitive restriction enzymes (HpaII and $\mathrm{CfoI}$ ) close to the polymorphism allow the determination of the active (unmethylated) and the inactive (methylated) allele [20]. After restriction enzyme digestion of the DNA and subsequent PCR amplification with a fluorophore-labeled forward primer, fragment analysis was carried out using a Beckman CEQ-8800 sequencer. The calculations for determining XI patterns were performed as described previously [21]. XI ratios between $50: 50$ and $65: 35 \%$ were scored as random, $66: 34-80: 20 \%$ as moderately skewed and $>80: 20 \%$ as highly skewed [22]. Two samples with known XI patterns (a random one with a proportion of $50: 50 \%$ and a nonrandom one with a proportion of 100:0\%) were used as controls.

\section{Results}

Although growth retardation and underweight are not rare among XLHED patients (male and female), anthropometric assessment of our cohort (mean age: 32.88, SD: 12.63) revealed no abnormalities (mean body length: $166.31 \mathrm{~cm}$, SD: 4.76; mean body weight: $70.41 \mathrm{~kg}$, SD: 14.75; mean BMI: 25.81, SD: 5.24) [23-25]. The mean number of deciduous teeth in the maxilla was 9.1 (SD: 1.37 ) and in the mandible 9.0 (SD: 1.63), however, data were not ascertainable in six out of 16 cases (38\%). On average, the total number of permanent teeth in the upper jaw was 11.38 (SD: 2.28) and 10.19 (SD: 3.73) in the lower jaw. Except for one subject (F6_S1), all women were missing deciduous and/or permanent teeth, but with a high variability (Table 1 ).

$56 \%$ of the affected women suffered from additional diseases, of which specific allergies, urticaria, neurodermatitis and eczema might be associated with their XLHED carrier status. Furthermore, six out of 16 women (38\%) reported to be photophobic and three (19\%) had experienced recurrent conjunctivitis. Hearing impairments occurred in two (13\%) of the patients (Table 2).

XLHED-related phenotypic features were assessed by the Face2Gene facial recognition algorithm and by patient questionnaires during the annual family conference of the German-Swiss-Austrian ectodermal dysplasia patient organization or during visits at the Center for Ectodermal Dysplasias in Erlangen. Except for two patients (F1_S2 and F6_S1), XLHED was among the list of possible syndrome matches suggested by Face2Gene (Gestalt Scores ranging from 0.06 to 0.38; male XLHED patients usually show scores of approximately 1.0, data not published). XLHED was not one of the syndrome matches suggested by Face2Gene when analyzing the

Table 1 Anthropometric measurements and tooth quantification

\begin{tabular}{|c|c|c|c|c|c|c|c|c|}
\hline \multirow[t]{2}{*}{ Code } & \multirow[t]{2}{*}{ Age } & \multirow[t]{2}{*}{ Length (in $\mathrm{cm}$ ) } & \multirow[t]{2}{*}{ Weight (in kg) } & \multirow[t]{2}{*}{ BMI } & \multicolumn{2}{|c|}{ Number of deciduous teeth } & \multicolumn{2}{|c|}{$\begin{array}{l}\text { Number of permanent } \\
\text { teeth }\end{array}$} \\
\hline & & & & & Maxilla & Mandible & Maxilla & Mandible \\
\hline F1_S1 & 16 & 167 & 52 & 19 & 8 & 6 & 12 & 10 \\
\hline F1_S2 & 19 & 165 & 70 & 26 & 9 & 10 & 13 & 14 \\
\hline F1_M & 50 & 170 & 70 & 24 & $\mathrm{n} / \mathrm{a}$ & $n / a$ & 5 & 0 \\
\hline $\mathrm{F} 2 \_\mathrm{S} 1$ & 20 & 159 & 53 & 26 & 10 & 6 & 8 & 5 (+ 1 DT) \\
\hline F2_S2 & 17 & 170 & 63 & 22 & 10 & 10 & 12 & 12 \\
\hline F2_M & 44 & 163 & 68 & 26 & 10 & 10 & 11 & 11 \\
\hline F3_S1 & 40 & 165 & 115 & 42 & $\mathrm{n} / \mathrm{a}$ & $\mathrm{n} / \mathrm{a}$ & 11 (+ 1 DT) & 9 \\
\hline F3_S2 & 37 & 157 & 70 & 28 & $\mathrm{n} / \mathrm{a}$ & $\mathrm{n} / \mathrm{a}$ & 14 & 11 \\
\hline F4_S1 & 23 & 170 & 60.5 & 21 & 6 & 9 & 10 & 11 (+2 DT) \\
\hline F4_S2 & 21 & 165 & 55 & 20 & 8 & 9 & 11 & 13 \\
\hline F4_M & 49 & 168 & 74 & 26 & $\mathrm{n} / \mathrm{a}$ & $\mathrm{n} / \mathrm{a}$ & 12 & 13 \\
\hline F5_S1 & 32 & 172 & 73 & 25 & 10 & 10 & 13 & 14 \\
\hline F5_S2 & 36 & 176 & 78 & 25 & 10 & 10 & 12 & 10 \\
\hline F6_S1 & 31 & 163 & 75 & 28 & 10 & 10 & 14 & 14 \\
\hline F6_S2 & 36 & 166 & 82 & 30 & $\mathrm{n} / \mathrm{a}$ & $\mathrm{n} / \mathrm{a}$ & 11 & 7 \\
\hline F6_M & 55 & 165 & 68 & 25 & $\mathrm{n} / \mathrm{a}$ & $\mathrm{n} / \mathrm{a}$ & 13 & 9 \\
\hline Average & 32.88 & 166.31 & 70.41 & 25.81 & 9.1 & 9.0 & 11.38 & 10.19 \\
\hline SD & 12.63 & 4.76 & 14.75 & 5.24 & 1.37 & 1.63 & 2.28 & 3.73 \\
\hline
\end{tabular}


Table 2 Medical history

\begin{tabular}{|c|c|c|c|c|}
\hline \multirow[t]{2}{*}{ Code } & \multirow[t]{2}{*}{ Diseases other than XLHED } & \multicolumn{2}{|c|}{ Recurrent eye problems } & \multirow{2}{*}{$\begin{array}{l}\text { Hearing } \\
\text { impairment }\end{array}$} \\
\hline & & Photophobia & Conjunctivitis & \\
\hline F1_S1 & Allergy & $\mathrm{N}$ & N & N \\
\hline F1_S2 & NAD & $\mathrm{N}$ & $\mathrm{N}$ & $\mathrm{N}$ \\
\hline F1_M & NAD & $\mathrm{N}$ & $\mathrm{N}$ & $\mathrm{N}$ \\
\hline F2_S1 & Urticaria, neurodermatitis & Y & Y & Y \\
\hline F2_S2 & NAD & Y & $\mathrm{N}$ & N \\
\hline F2_M & NAD & Y & $\mathrm{N}$ & $\mathrm{N}$ \\
\hline F3_S1 & Diabetes & Y & N & Y \\
\hline F3_S2 & NAD & Y & N & N \\
\hline F4_S1 & NAD & N & $\mathrm{N}$ & N \\
\hline F4_S2 & Hashimoto's thyroiditis & $\mathrm{N}$ & Y & $\mathrm{N}$ \\
\hline F4_M & Hypothyroidism & $\mathrm{N}$ & Y & $\mathrm{N}$ \\
\hline F5_S1 & Glaucoma & Y & $\mathrm{N}$ & $\mathrm{N}$ \\
\hline F5_S2 & Hypothyroidism & N & $\mathrm{N}$ & $\mathrm{N}$ \\
\hline F6_S1 & Hypothyroidism & $\mathrm{N}$ & $\mathrm{N}$ & $\mathrm{N}$ \\
\hline F6_S2 & Allergy, eczema & $\mathrm{N}$ & $\mathrm{N}$ & $\mathrm{N}$ \\
\hline F6_M & NAD & N & N & N \\
\hline
\end{tabular}

Abbreviations: F, family; S, sister; $M$, mother; NAD, no abnormality detected; $Y$, yes; $N$, no

portrait pictures of unaffected mothers who served as negative controls.

Eleven out of 16 subjects (69\%) reported skin problems like dry and eczematous skin or neurodermatitis. Furthermore, 13 women showed sparse and/or thin scalp hair (81\%), sparse eyebrows (81\%) and in ten cases also sparse eyelashes $(63 \%)$. Breast abnormalities, often associated with breastfeeding difficulties, were noted in twelve (75\%) of the patients (Table 3 ).

Heat intolerance was reported by six out of 16 women (38\%), although all subjects were able to sweat in at least some areas of their body. Hypohidrosis impaired daily life in four subjects (25\%) and sporting activities in seven (44\%) of the patients (Table 4). Pilocarpine-induced sweat volume on the forearm was $28.3 \mu \mathrm{l}$ on average (SD: 23.5) and was ranging from complete anhidrosis (F1_S1) to normal sweating ability (Fig. 1; mean pilocarpineinduced sweat volume of healthy women: $61 \mu \mathrm{l}$ [6]).

All familial variants identified in this study are known to be pathogenic and are associated with severe phenotypes in affected males (Table 5) [18,26-29]. None of the participants carried the potentially compensating SNP rs3827760 in the gene EDAR. The HUMARA assay revealed that eleven out of 16 affected women $(69 \%)$ display random, four $(25 \%)$ moderately, and one $(6 \%)$ highly skewed XI patterns. None of our female patients showed a complete inactivation of one of the two X chromosomes. Among the five cases with skewed XI, this was in favour of the wild-type allele (indicated by the higher XI ratio for the mutated allele) only in patient F4_M, while in the remaining four women (F3_S1, F5_S1, F6_S1 and F6_S2) the mutated allele was the preferentially active one (Table 5).

A comparison of the sweating abilities and XI patterns revealed no distinct correlation (limitations of this assessment are discussed later in the text). For example, the families F1 and F2 show distinct intrafamilial variations with regard to their sweating abilities, but these differences are not reflected by their XI status (all members with random XI ratios). Although patient F3_S1 with negligible sweat production was found to have skewed $\mathrm{XI}$ in favour of the mutation-carrying cells, the complete opposite was true for F6_S1, a woman with a similar XI pattern (also in favour of the mutated allele) but almost normal sweating ability.

\section{Discussion}

One of the aims of this study was to gather and compare XLHED-related phenotypic features of females carrying pathogenic EDA variants, a group of patients who received only little scientific attention so far. Furthermore, we intended to find out whether variations in the expression of XLHED-related symptoms might be explained by deviating XI patterns as already reported for other X-linked diseases. In these cases, women escape the normally balanced mosaicism and show an increased expression level in one of the cell populations, or a decreased one, respectively.

The portion of patients with nonrandom XI patterns in our cohort is marginally higher than in the general female 
Table 3 Phenotypic features

\begin{tabular}{|c|c|c|c|c|c|c|}
\hline Code & $\begin{array}{l}\text { Gestalt Score* } \\
(0-1)\end{array}$ & Skin & Scalp hair & Eyebrows & Eyelashes & Breast \\
\hline F1_S1 & 0.1 & Partially dry & NAD & Sparse (esp. laterally) & NAD & Size asymmetry \\
\hline F1_S2 & u.a & NAD & NAD & NAD & NAD & NAD \\
\hline F1_M & 0.15 & Dry & Sparse, thin & Very sparse & Very sparse & $\begin{array}{l}\text { No mammary gland } \\
\text { (left), no breastfeeding } \\
\text { (voluntarily) }\end{array}$ \\
\hline F2_S1 & 0.1 & $\begin{array}{l}\text { Neurodermatitis, dry } \\
\text { scalp }\end{array}$ & Partially sparse & Sparse & Sparse & Soft mamillae \\
\hline F2_S2 & 0.15 & NAD & Thin, strawy & Sparse (esp. laterally) & Sparse (esp. laterally) & NAD \\
\hline F2_M & 0.12 & Thin skin, partially dry & $\begin{array}{l}\text { Sparse, bald spots } \\
\text { (occipital) }\end{array}$ & Sparse & Sparse & Breastfeeding difficulties \\
\hline F3_S1 & 0.16 & Partially eczematous, dry & $\begin{array}{l}\text { Sparse, bald spots (hair- } \\
\text { line and lateral) }\end{array}$ & Sparse (esp. laterally) & Sparse & Flat mamillae \\
\hline F3_S2 & 0.13 & Very dry & NAD & NAD & Sparse & Size asymmetry \\
\hline F4_S1 & 0.16 & NAD & Rather sparse & Sparse (esp. laterally) & NAD & NAD \\
\hline F4_S2 & 0.37 & Partially dry & Rather sparse & Sparse (esp. laterally) & NAD & NAD \\
\hline F4_M & 0.27 & Dry & Sparse, thin & Rather sparse & NAD & Flat mamillae \\
\hline F5_S1 & 0.06 & Dry & Rather sparse & Rather sparse & Rather sparse & Breastfeeding difficulties \\
\hline F5_S2 & 0.15 & NAD & Rather sparse, thin & Sparse (esp. laterally) & Rather sparse & $\begin{array}{l}\text { No breastfeeding, benign } \\
\text { tumor }\end{array}$ \\
\hline F6_S1 & u.a & NAD & Partially sparse & NAD & NAD & $\begin{array}{l}\text { Breastfeeding difficulties } \\
\text { due to small mamillae }\end{array}$ \\
\hline F6_S2 & 0.38 & $\begin{array}{l}\text { Eczematous (permanent } \\
\text { steroid treatment) }\end{array}$ & Sparse & Sparse (esp. laterally) & Sparse & Breastfeeding difficulties \\
\hline F6_M & 0.15 & Psoriasis & Partially sparse & Sparse & Sparse & Breastfeeding difficulties \\
\hline
\end{tabular}

Abbreviations: *, rounded; F, family; S, sister; M, mother; u.a., unable to assess; NAD, no abnormality detected; esp., especially

Table 4 Data related to sweating ability and heat intolerance

\begin{tabular}{|c|c|c|c|c|}
\hline \multirow[t]{2}{*}{ Code } & \multirow[t]{2}{*}{$\begin{array}{l}\text { Reported heat } \\
\text { intolerance }\end{array}$} & \multirow[t]{2}{*}{$\begin{array}{l}\text { Body areas } \\
\text { with reported } \\
\text { sweating ability }\end{array}$} & \multicolumn{2}{|c|}{$\begin{array}{l}\text { Reported impact } \\
\text { of reduced } \\
\text { sweating on: }\end{array}$} \\
\hline & & & Daily life & Sports \\
\hline F1_S1 & Y & Y & $\mathrm{N}$ & Y \\
\hline F1_S2 & $N$ & Y & $N$ & $\mathrm{~N}$ \\
\hline F1_M & $N$ & Y & $\mathrm{N}$ & Y \\
\hline F2_S1 & Y & Y & Y & Y \\
\hline F2_S2 & $N$ & Y & $\mathrm{N}$ & Y \\
\hline F2_M & $N$ & Y & $\mathrm{N}$ & $\mathrm{N}$ \\
\hline F3_S1 & Y & Y & Y & Y \\
\hline F3_S2 & $N$ & Y & $\mathrm{N}$ & $N$ \\
\hline F4_S1 & $N$ & Y & $\mathrm{N}$ & $\mathrm{N}$ \\
\hline F4_S2 & $N$ & Y & $\mathrm{N}$ & $\mathrm{N}$ \\
\hline F4_M & Y & Y & $\mathrm{N}$ & $\mathrm{N}$ \\
\hline F5_S1 & $\mathrm{N}$ & Y & $\mathrm{N}$ & Y \\
\hline F5_S2 & $N$ & Y & $\mathrm{N}$ & $N$ \\
\hline F6_S1 & $N$ & Y & $\mathrm{N}$ & $\mathrm{N}$ \\
\hline F6_S2 & Y & Y & Y & $N$ \\
\hline F6_M & Y & Y & Y & Y \\
\hline
\end{tabular}

Abbreviations: $\mathrm{F}$, family; $\mathrm{S}$, sister; $\mathrm{M}$, mother; $\mathrm{Y}$, yes; $\mathrm{N}$, no

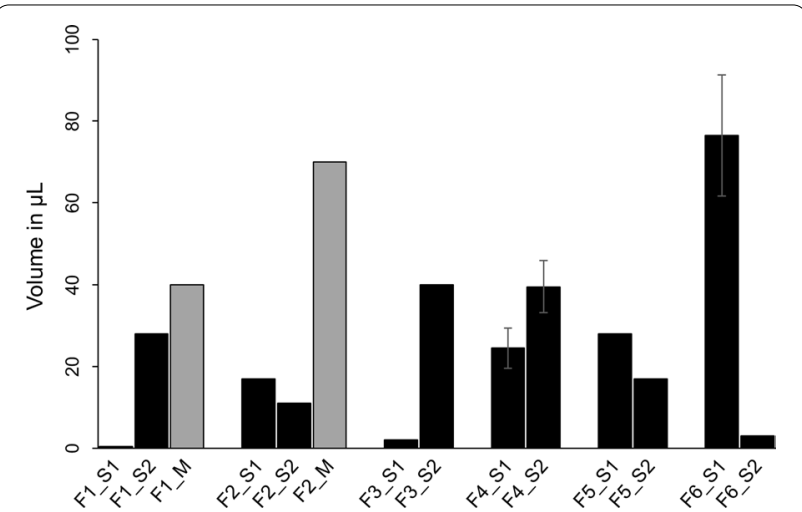

Fig. 1 Quantification of pilocarpine-induced sweat production (volume in $\mu \mathrm{L}$ ). Sisters are represented in black, mothers (whenever available for sweat collection) in grey

population, as approximately $10-30 \%$ (age-dependent) of unaffected women present skewed XI patterns (deviations of percentage rates found in the literature result from variable definitions of the threshold values for the XI ratios) [21,30-32]. The previously reported relation between the age of the women and higher skewing rates 
Table 5 EDA genotypes of affected individuals and X-chromosome inactivation patterns

\begin{tabular}{|c|c|c|c|c|c|}
\hline Code & EDA variant & $\begin{array}{l}\text { Changes } \\
\text { at the amino acid } \\
\text { level }\end{array}$ & Predicted effect & $\begin{array}{l}\mathrm{XI} \text { ratios in \% } \\
(\mathrm{A} 1: \mathrm{A} 2)^{*}\end{array}$ & Classification \\
\hline F1_S1 & c.64_71dup8 & p.Cys25AlafsX35 & Truncated, dysfunctional protein, possibly causing NMD & $51: 49$ & Random \\
\hline F1_S2 & c.64_71dup8 & p.Cys25AlafsX35 & Truncated, dysfunctional protein, possibly causing NMD & $54: 46$ & Random \\
\hline F1_M & c.64_71dup8 & p.Cys25AlafsX35 & Truncated, dysfunctional protein, possibly causing NMD & $47: 53$ & Random \\
\hline F2_S1 & C.917A $>\mathrm{G}$ & p.Gln306Arg & Impaired receptor binding & 37:63 & Random \\
\hline F2_S2 & C. $917 A>G$ & p.GIn306Arg & Impaired receptor binding & 51:49 & Random \\
\hline F2_M & c. $917 A>G$ & p.GIn306Arg & Impaired receptor binding & $64: 36$ & Random \\
\hline F3_S1 & $c .871 \mathrm{G}>\mathrm{A}$ & p.Gly291Arg & Impaired receptor binding & 31:69 & Moderately skewed \\
\hline F3_S2 & $c .871 \mathrm{G}>\mathrm{A}$ & p.Gly291Arg & Impaired receptor binding & $65: 35$ & Random \\
\hline F3_F & c. $871 \mathrm{G}>\mathrm{A}$ & p.Gly291Arg & Impaired receptor binding & / & / \\
\hline F4_S1 & c. $467 \mathrm{G}>\mathrm{A}$ & p.Arg156His & Abolished furin cleavage & $46: 54$ & Random \\
\hline F4_S2 & c. $467 \mathrm{G}>\mathrm{A}$ & p.Arg156His & Abolished furin cleavage & 39:61 & Random \\
\hline F4_M & c. $467 \mathrm{G}>\mathrm{A}$ & p.Arg156His & Abolished furin cleavage & $30: 70$ & Moderately skewed \\
\hline F5_S1 & C. $1045 G>A$ & p.Ala349Thr & Impaired receptor binding & $76: 24$ & Moderately skewed \\
\hline F5_S2 & C. $1045 G>A$ & p.Ala349Thr & Impaired receptor binding & $61: 39$ & Random \\
\hline F5_F & c. $1045 G>A$ & p.Ala349Thr & Impaired receptor binding & / & / \\
\hline F6_S1 & c. $1133 C>T$ & p.Thr378Met & Impaired receptor binding & $81: 19$ & Highly skewed \\
\hline F6_S2 & C. $1133 C>T$ & p.Thr378Met & Impaired receptor binding & $71: 29$ & Moderately skewed \\
\hline F6_M & c. $1133 C>T$ & p.Thr378Met & Impaired receptor binding & $54: 46$ & Random \\
\hline
\end{tabular}

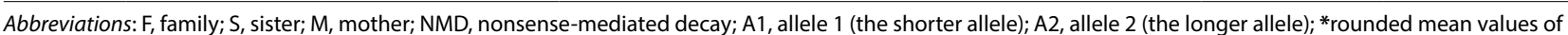
the experiments using $\mathrm{Hpall}$ and $\mathrm{Cfol}$, respectively; bold values mark the alleles with the disease-causing EDA variant

was not observed in our group of patients, which might be due to the limited cohort size.

We did not find a distinct correlation between disease manifestation and the XI pattern, concluding that XI is not the only explanation for phenotypic differences between female carriers of the same pathogenic EDA variant. Martínez-Romero et al. report similar results in their cohort of female XLHED patients in Spain [16]. Although XI patterns are usually comparable among the different tissues of the same individual, cases of tissuespecific discordance have been reported, too. Furthermore, this variability seems to be age-dependent and is particularly evident in women older than 60 years [3235]. Peripheral blood leukocytes are commonly used for the investigation of selection mechanisms in XI-associated diseases, not only due to their easy accessibility but also to the high cell division rate. This leads to a higher selection pressure on cells carrying proliferation-inhibiting mutations and therefore on average to slightly higher rates of skewed XI [36,37]. The XI patterns of blood and saliva in a Danish XLHED cohort showed a strong correlation [38]. Although determination of XI patterns in peripheral blood leukocytes by the HUMARA assay is a well-established procedure, there are limitations of the method and the current study. For example, the HUMARA assay is not informative in approximately $10 \%$ of the female population, so that other techniques have to be applied. In such cases, the XI status could be determined at the RNA level by analyzing the expression of informative X-linked polymorphisms [39]. Furthermore, tissue-specific variations of XI ratios cannot be excluded, but DNA from a sufficient number of skin biopsies or teeth is usually not available.

Cutaneous mosaicism, however, may present in different patterns, such as patches or lateralization, or following the linear lines of Blaschko. As we do not know whether the skin area where sweat was collected is affected or not, we cannot conclude much about the correlation between XI patterns and sweating ability.

Interestingly, several female patients reported about local differences (distinct from the lines of Blaschko) regarding the phenotypic expression, namely unilaterally reduced hair growth and sweating ability. The reason for lateralization, which has already been observed in other skin diseases, remains unclear [40].

Generally, skewed XI patterns can be evoked either by chance as a stochastic event, due to an impairment of the XI process itself (e. g. mutations in the XI-specific XIST gene) or because of selection mechanisms (the latter is hypothesized to occur more often in carriers of X-linked disorders [41, 42]. However, a selective advantage of one of the cell populations is always unidirectional and can therefore be excluded, as we found skewed XI ratios both in favour of the wild-type and the mutant allele. 
The different pathogenic $E D A$ variants of the six families are known to lead to comparable, full-blown clinical symptoms of XLHED in male patients. None of the patients carried the EDAR SNP rs3827760, a variant reported to potentially attenuate the severity of XLHEDrelated signs [5]. Nevertheless, other genetic or epigenetic factors, such as yet undetected polymorphisms, might have an impact on the patients' phenotypes. They could be detected by future whole exome sequencing and subsequent genotype-phenotype association studies.

\section{Conclusions}

Although we neither found higher rates of nonrandom XI in our patients nor a distinct correlation between skewed $\mathrm{XI}$ ratios and phenotypic expression levels, it is conceivable that in some cases extremely shifted levels might have protective or pathogenic effects, respectively. Our research accentuates the need for further large-cohort studies (comparing not only family members, but also unrelated female carriers of the same $E D A$ genotype) for final conclusions. This, however, might be challenging because of the rarity of XLHED and the fact that asymptomatic carriers without affected male relatives usually remain undetected. Moreover, a determination of generally accepted criteria for the classification of XLHED phenotypes as mild, moderate or severe will be needed for more objective evaluations. This study is the first systematic approach to phenotyping in female XLHED patients, which might be relevant for the question whether a medical treatment option currently explored in clinical trials should also be considered for affected females.

\section{Abbreviations}

ED: Ectodermal dysplasia; EDA: Ectodysplasin A; HED: Hypohidrotic ectodermal dysplasia; HUMARA: The human androgen receptor assay; SNP: Singlenucleotide polymorphism; XI: X-chromosome inactivation; XLHED: X-linked hypohidrotic ectodermal dysplasia.

\section{Acknowledgements \\ We are very grateful to all patients and their families for participating in our study and to the Zangger Foundation (Switzerland) for funding. Furthermore we thank Dr. J. A. Lee and Dr. J. Jones (Greenwood Genetic Center) for provid- ing us DNA samples with different XI patterns as positive controls. Two of the authors of this publication are members of the European Reference Network (ERN) Skin, project ID number 739543.}

\section{Authors' contributions \\ HS and SMW conceptualized and designed the study. LK, HS and SMW col- lected and evaluated data, drafted the initial manuscript, and reviewed and revised it. NF carried out the Face2Gene analyses and critically reviewed the manuscript for intellectual content. Most of the work was performed by LK in fulfillment of the requirements for obtaining the degree Dr. med. from the Friedrich-Alexander University Erlangen-Nürnberg. All authors approved the final manuscript as submitted and agree to be accountable for all aspects of the work.}

\section{Authors' information}

NF is an employee of FDNA Inc., the company developing Face2Gene.

\section{Funding}

Open Access funding enabled and organized by Projekt DEAL. This study was funded by the Zangger Foundation (research grant to HS).

\section{Availability of data and materials}

The datasets used and analysed during the current study are available from the corresponding author on reasonable request.

\section{Consent for publication \\ Not applicable.}

\section{Ethics approval and consent to participate}

This study was approved by the ethics committee of the University ErlangenNürnberg. All individuals gave written informed consent to participate (including consent to the use of their blood, respectively DNA, for molecular analysis). The study was conducted in accordance with the principles of the declaration of Helsinki.

\section{Competing interests}

The authors declare that they have no competing interests.

\section{Author details}

${ }^{1}$ Center for Ectodermal Dysplasias and Department of Pediatrics, University Hospital Erlangen, Loschgestr. 15, 91054 Erlangen, Germany. ${ }^{2}$ FDNA Inc, Boston, MA, USA.

Received: 30 October 2020 Accepted: 9 February 2021

Published online: 23 February 2021

\section{References}

1. Itin PH, Fistarol SK. Ectodermal dysplasias. Am J Med Genet C. 2004;131:45-51.

2. Clarke A, Phillips DI, Brown R, Harper PS. Clinical aspects of X-linked hypohidrotic ectodermal dysplasia. Arch Dis Child. 1987;62:989-96.

3. Blüschke G, Nüsken KD, Schneider H. Prevalence and prevention of severe complications of hypohidrotic ectodermal dysplasia in infancy. Early Hum Dev. 2010;86:397-9.

4. Kere J, Srivastava AK, Montonen O, Zonana J, Thomas N, Ferguson B, et al. $\mathrm{X}$-linked anhidrotic (hypohidrotic) ectodermal dysplasia is caused by mutation in a novel transmembrane protein. Nat Genet. 1996;13:409-16.

5. Cluzeau C, Hadj-Rabia S, Bal E, Clauss F, Munnich A, Bodemer C, et al. The EDAR370A allele attenuates the severity of hypohidrotic ectodermal dysplasia caused by EDA gene mutation. Br J Dermatol. 2012;166:678-81.

6. Schneider H, Hammersen J, Preisler-Adams S, Huttner K, Rascher W, Bohring A. Sweating ability and genotype in individuals with $X$-linked hypohidrotic ectodermal dysplasia. J Med Genet. 2011;48:426-32.

7. Al-Jassim AH, Swift AC. Persistent nasal crusting due to hypohidrotic ectodermal dysplasia. J Laryngol Otol. 1996;110:379-82.

8. Kaercher T. Ocular symptoms and signs in patients with ectodermal dysplasia syndromes. Graefes Arch Clin Exp Ophthalmol. 2004;242:495-500.

9. Dietz J, Kaercher T, Schneider AT, Zimmermann T, Huttner K, Johnson R, et al. Respiratory and ocular involvement in X-linked hypohidrotic ectodermal dysplasia. Eur J Pediatr. 2013;172:1023-31.

10. Lindfors PH, Voutilainen M, Mikkola ML. Ectodysplasin/NF-kappaB signaling in embryonic mammary gland development. J Mammary Gland Biol Neoplasia. 2013;18:165-9.

11. Wahlbuhl-Becker M, Faschingbauer F, Beckmann MW, Schneider $\mathrm{H}$. Hypohidrotic ectodermal dysplasia: breastfeeding complications due to impaired breast development. Geburtshilfe Frauenheilkd. 2017;77:377-82.

12. Lyon MF. Gene action in the X-chromosome of the mouse (Mus musculus L.). Nature. 1961;190:372-3.

13. Pavlovsky M, Fuchs-Telem D, Nousbeck J, Sarig O, Sprecher E. Molecular evidence for the role of $\mathrm{X}$-chromosome inactivation in linear presentation of X-linked hypohidrotic ectodermal dysplasia. Clin Exp Dermatol. 2012;37:186-8

14. Lei K, Zhang Y, Dong Z, Sun Y, Yi Z, Chen Z. A novel 1-bp deletion mutation and extremely skewed $X$-chromosome inactivation causing severe 
X-linked hypohidrotic ectodermal dysplasia in a Chinese girl. Clin Exp Dermatol. 2018;43:60-2.

15. Milovidova TB, Schagina OA, Freire MV, Demina NA, Filatova AY, Skoblov MY, et al. X-linked hypohidrotic ectodermal dysplasia: clinical and molecular genetic analysis of a large Russian family with a synonymous p.Ser267 $=(c .801 \mathrm{~A}>\mathrm{G})$ splice site mutation. J Eur Acad Dermatol Venereol. 2019:33:e468-70

16. Martínez-Romero MC, Ballesta-Martínez MJ, López-González V, SánchezSoler MJ, Serrano-Antón AT, Barreda-Sánchez M, et al. EDA, EDAR, EDARADD and WNT10A allelic variants in patients with ectodermal derivative impairment in the Spanish population. Orphanet J Rare Dis. 2019;14:281

17. Schneider H, Faschingbauer F, Schuepbach-Mallepell S, Körber I, Wohlfart $\mathrm{S}$, Dick A, et al. Prenatal correction of X-linked hypohidrotic ectodermal dysplasia. N Engl J Med. 2018;378:1604-10.

18. Wohlfart S, Hammersen J, Schneider H. Mutational spectrum in 101 patients with hypohidrotic ectodermal dysplasia and breakpoint mapping in independent cases of rare genomic rearrangements. J Hum Genet. 2016;61:891-7.

19. Gurovich Y, Hanani Y, Bar O, Nadav G, Fleischer N, Gelbman D, et al. Identifying facial phenotypes of genetic disorders using deep learning. Nat Med. 2019;25:60-4.

20. Allen RC, Zoghbi HY, Moseley AB, Rosenblatt HM, Belmont JW. Methylation of Hpall and Hhal sites near the polymorphic CAG repeat in the human androgen-receptor gene correlates with $\mathrm{X}$ chromosome inactivation. Am J Hum Genet. 1992:51:1229-39.

21. Jones JR. Nonrandom $X$ chromosome inactivation detection. Curr Protoc Hum Genet. 2014:80:9.7.1-7.

22. Harris A, Collins J, Vetrie D, Cole C, Bobrow M. X inactivation as a mechanism of selection against lethal alleles: further investigation of incontinentia pigmenti and X linked lymphoproliferative disease. J Med Genet. 1992:29:608-14.

23. Motil KJ, Fete TJ, Fraley JK, Schultz RJ, Foy TM, Ochs U, et al. Growth characteristics of children with ectodermal dysplasia syndromes. Pediatrics. 2005;116:e229-34.

24. Fete M, Hermann J, Behrens J, Huttner KM. X-linked hypohidrotic ectodermal dysplasia (XLHED): clinical and diagnostic insights from an international patient registry. Am J Med Genet A. 2014;164A:2437-42.

25. Mensink G, Schienkiewitz A, Haftenberger M, Lampert T, Ziese T, Scheidt Nave C. Übergewicht und Adipositas in Deutschland. Bundesgesundheitsbl. 2013;56:786-94.

26. Miyake T, Kiniwa Y, Kosho T, Nakano H, Okuyama R. Hypohidrotic ectodermal dysplasia: a report of two cases. J Dermatol. 2017:44:479-81.

27. Sekiguchi H, Wang XJ, Minaguchi K, Yakushiji M. A point mutation of the ED1 gene in a Japanese family with $X$-linked hypohidrotic ectodermal dysplasia. Int J Paediatr Dent. 2005;15:73-7.
28. Monreal AW, Zonana J, Ferguson B. Identification of a new splice form of the EDA1 gene permits detection of nearly all X-linked hypohidrotic ectodermal dysplasia mutations. Am J Hum Genet. 1998;63:380-9.

29. Schneider P, Street SL, Gaide O, Hertig S, Tardivel A, Tschopp J, et al. Mutations leading to X-linked hypohidrotic ectodermal dysplasia affect three major functional domains in the tumor necrosis factor family member Ectodysplasin-A. J Biol Chem. 2001;276:18819-27.

30. Kristiansen M, Knudsen GP, Bathum L, Naumova AK, Sørensen TI, Brixet $\mathrm{TH}$, et al. Twin study of genetic and aging effects on $\mathrm{X}$ chromosome inactivation. Eur J Hum Genet. 2005;13:599-606.

31. Gong X, Bacchelli E, Blasi F, Toma C, Betancur C, Chaste P, et al. Analysis of $X$ chromosome inactivation in autism spectrum disorders. Am J Med Genet B Neuropsychiatr Genet. 2008;147B:830-5.

32. Brown CJ, Robinson WP. The causes and consequences of random and non-random X chromosome inactivation in humans. Clin Genet. 2000:58:353-63.

33. Busque L, Mio R, Mattioli J, Brais E, Blais N, Lalonde Y, et al. Nonrandom $X$-inactivation patterns in normal females: lyonization ratios vary with age. Blood. 1996;88:59-65.

34. Bittel DC, Theodoro MF, Kibiryeva N, Fischer W, Talebizadeh Z, Butler MG Comparison of X-chromosome inactivation patterns in multiple tissues from human females. J Med Gene. 2008;45:309-13.

35. Sharp A, Robinson D, Jacobs P. Age- and tissue-specific variation of $X$ chromosome inactivation ratios in normal women. Hum Genet. 2000;107:343-9.

36. Migeon BR. Non-random X chromosome inactivation in mammalian cells. Cytogenet Cell Genet. 1998;80:142-8.

37. Lyon MF. X-chromosome inactivation and human genetic disease. Acta Paediatr Suppl. 2002;91:107-12.

38. Lexner MO, Bardow A, Juncker I, Jensen LG, Almer L, Kreiborg S, et al. X-linked hypohidrotic ectodermal dysplasia. Genetic and dental findings in 67 Danish patients from 19 families. Clin Genet. 2008;74:252-9.

39. Vacca M, Della Ragione F, Scalabrì F, D'Esposito M. X inactivation and reactivation in X-linked diseases. Semin Cell Dev Biol. 2016;56:78-87.

40. Imanishi H, Tsuruta D, Kobayashi H, Ishii M, Nakagawa K. Two cases of unilateral ashy dermatosis. Case Rep Dermatol. 2011;3:1-4.

41. Puck JM, Willard HF. X inactivation in females with X-linked disease. N Engl I Med. 1998:338:325-8.

42. Ørstavik KH. X chromosome inactivation in clinical practice. Hum Genet. 2009;126:363-73.

\section{Publisher's Note}

Springer Nature remains neutral with regard to jurisdictional claims in published maps and institutional affiliations.
Ready to submit your research? Choose BMC and benefit from:

- fast, convenient online submission

- thorough peer review by experienced researchers in your field

- rapid publication on acceptance

- support for research data, including large and complex data types

- gold Open Access which fosters wider collaboration and increased citations

- maximum visibility for your research: over $100 \mathrm{M}$ website views per year

At $\mathrm{BMC}$, research is always in progress.

Learn more biomedcentral.com/submissions 